\title{
Bir Şehircilik Problemi: Değişen İklimde Termal Konforu Sağlamak
}

\section{An Urbanism Challenge: Provision of Thermal Comfort in Changing Climate}

\section{Ender Peker}

İngiliz Araştırma Enstitüsü, Ankara

\section{ÖZ}

Bu makale, iklim değişikliği ile birlikte kentlerde artan termal konfor probleminden yola çıkarak, kentlerin iklim duyarlı tasarım yaklaşımıyla daha dirençli hale getirilebileceğini savunmaktadır. Türkiye kentlerinde süregelen kentleşme dinamiklerini iklime duyarlılık açısından eleştiren çalışma, hakim planlama uygulamalarının iklim değişikliğine uyum ve iklim değişikliği ile mücadele hedeflerine yeterince uyum gösteremediğinin altını çizmektedir. Araştırma, Mardin kentinin Artuklular döneminde örüntülenmeye başlayan geleneksel kent dokusu ve Cumhuriyet sonrası gelişen modern kent dokusu arasında karşılaştırma yaparak, üretilen mekanların hem iklime uyum ve hassasiyet, hem de yerel halkın yaşam tarzı ve kentsel mekanı kullanma pratiklerine uyumu açısından değerlendirmektedir. Karşılaştırmalı alan çalışması, kent mekanının günlük yaşam pratiklerinde deneyimlenen kentsel termal konfor üzerindeki etkisini anlamak üzere kurgulanmıştır. Mardin ili örneği üzerinden yürütülen çalışma, hakim kentleşme koşullarının, iklim değişikliğinin etkileriyle beraber artması beklenen sıcaklık değerleri ve sıcak dalgası sıklıklarına karşın kentlileri kırılgan bir konumda bıraktığını göstermektedir.

Anahtar sözcükler: İklim değişikliği; iklim duyarlı mekan üretimi; kentsel tasarım; termal konfor.

\begin{abstract}
Taking the challenges of provision of thermal comfort as a point of departure, this paper argues that climate responsive urban design has great potential to make cities more resilient to climate change. With a concern of climate responsivity, this research brings a critical perspective on the current urbanization trends in Turkish cities and underlines the inconsistence nature of ongoing urban developments with the foreseen climate change adaptation and mitigation policies. The research is constructed based on a comparative study between the traditional urban pattern that has been developed since the Artuqids era and the contemporary urban pattern that has been developed from the $60 \mathrm{~s}$ in the province of Mardin. The comparative study focused on responsivity of the produced urban spaces both in terms of both the climatic conditions and the ways which local people uses the urban space. While doing that, the research explored the role of urban space on the provision of urban thermal comfort in everyday life. The research revealed that existing development trends in Mardin leave citizens vulnerable to the negative effects of increasing temperature values and potential heat waves in future.

Keywords: Climate change; climate responsive space production; urban design; thermal comfort.
\end{abstract}

Geliş tarihi: 30.07.2019 Kabul tarihi: 06.10.2020

Online yayımlanma tarihi: I6.02.202I

Iletişim: Ender Peker

e-posta: pekerender@gmail.com 


\section{Giriş}

Hükümetlerarası İklim Değişikliği Paneli'nin (IPCC) (2007) 4. değerlendirme raporu, bazı coğrafyalarda yaz sıcaklık ortalamalarının artması ile birlikte klimaya bağlı iklimlendirme ihtiyacının artması ve bu ihtiyacın binalarda enerji tüketimini arttırdığına dikkat çekmektedir. Rapor, coğrafyalar arası sosyo-kültürel çeşitliliğin önemini vurgularken, bazı coğrafyalarda (ör: Pasifikler'in bazı bölgeleri) geleneksel konut üretim modellerinden uzaklaşılmasının yerel halkı termal strese karşı savunmasız kıldığını ve bu bölgelerde klimaya bağlılı̆ın giderek arttığını ortaya koymaktadır. Benzer şekilde, Kentsel İklim Değişikliğini Araştırma Ağı'nın (UCCRN) (20I8) 2. değerlendirme raporu da, farklı bölgelerde termal konforu sağlamanın zorlaşmasına bağı karbon emisyonlarındaki artışlara dikkat çekerken, iklim değişikliğinin farklı sosyo-kültürel bağlamlardaki etkilerinin de değişkenlik gösterdiğini vurgulamaktadır. Uluslararası bilimsel ağlar tarafından yayımlanan bu raporlar, kentlerde termal konforun sağlanmasının giderek zorlaştı̆̆ına dikkat çekmektedir. Türkiye'nin de içinde yer aldığı coğrafyada artması öngörülen sıcaklık ortalamaları ve sıklaşması beklenen sıcak dalgaları (heat wave) (Şahin, 2019), kentlerin bu değişime hazır ve dirençli olması ihtiyacını doğurmaktadır.

Bilimsel araştırmalar kentsel yapılı çevrenin kentsel mikro iklim üzerinde yadsınamaz bir etkisi olduğunu göstermektedir (Erell vd. 2010; Gut ve Ackerknecht, 1993; Oke, 1987). Yapılı çevrenin oluşumundan kaynaklanan mikro iklimsel farklılıklar da, direk veya dolaylı yollar ile iklim değişikliğine girdi yapan olumsuz faktörlerin belirleyicisi olmaktadır. Örneğin, kentsel mekanda termal konforun sağlanması yüksek oranlarda enerji tüketim ihtiyacını doğururken, mekan üretimindeki akıllı ve duyarlı yaklaşımlar, tüketilen enerji miktarını ve bağlantılı olarak salınan karbon değerlerini azaltmaya olanak sağlamaktadır. Bu bağlamda, mimarlık yazınından doğan 'pasif tasarım' (passive design) yaklaşımı, doğal kaynaklardan en üst düzeyde faydayı sağlayarak konut mekanlarında ısıtma ve soğutma ihtiyaçlarını karşılamak üzere tüketilen enerjiyi en aza indirgemeyi hedeflemektedir (Gao vd. 2012; Krüger vd. 201 I; Ochoa ve Capeluto, 2008). Benzer şekilde, yine mimarlık yazınından doğan 'iklim duyarlı tasarım' (climate responsive design) yaklaşımı, konut mekanlarında enerji tüketimini azaltarak, optimum termal konforun sağlanmasını amaçlamaktadır (Hyde, 2000; Energy Design Resources, 20I0). Uluslararası yazında kullanılan 'responsive' kavramı iklim ve tasarım arasındaki iki yönlü ilişkiyi vurgularken, hassasiyet anlamının ötesinde, iklim değişkenlerini anlayan ve ona karşı bir cevap geliştirebilen, esnek bir tasarım anlayışını ifade etmektedir.

Bu çalışma, bina ölçeğine odaklanan iklim duyarlı tasarım yaklaşımının kentsel ölçekteki yansımalarını tartışmaya açarak, mimari yazından doğan tasarım prensiplerinin sokak, mahalle ve kent ölçeğinde de ele alınması gerekliliğini savunmaktadır.
Bu doğrultuda, çalışma, iklim değişikliğine dirençli kent mekanları üretebilmenin geleneksel planlama yaklaşımı ve imar uygulamalarından öte, iklim duyarlı kentsel tasarım nosyonunun şehircilik pratiğine aktarılabilmesi ile mümkün olabileceğini iddia etmektedir. Bu konu, kentlerimizin iklim değişikliğine olan katkısı ve kent içi mikro iklim değerlerindeki değişkenlikleri önlemek açısından büyük önem taşımaktadır.

\section{Kentsel Termal Konfor ve İklim}

Yazına göre, kentsel termal konfor seviyesi yaşam kalitesini etkilediği gibi, iç mekanlarda deneyimlenen konforu ve konforun sağlanması için tüketilen enerji miktarlarını da etkilemektedir (Deb ve Ramachandraiah, 20ll). Yao vd. (20l2), kent formunun, güneşlenme süresi üzerindeki rolü ve gün ışığı ile doğal havalandırmadan faydalanmadaki etkisinden ötürü, enerji tüketimi üzerinde de belirleyici bir rolü olduğunun altını çizmektedir. Yapılan araştırmalar (bkz. Shashua-Bar vd. 2012; Krüger vd. 20I I) iklim duyarlı tasarım ilkeleri sayesinde daha az enerji tüketimi ile iç ve dış mekanlarda optimum konforun sağlanmasının mümkün olabileceğini göstermektedir. Burada önemli olan nokta, kentsel mekanda termal konforun sağlanabilmesi için kenti oluşturan alt-bileşenler ve mekânsal ölçeklerdeki gerekli iklimsel duyarlılık alanlarının tespit edilmesidir. Bu noktada, ölçekler arası farklılıklar ve ölçeklerin birlikte düşünülerek kentin geleceğinin bütüncül bir şekilde tasarlanması gerekmektedir. Bir başka ifadeyle, burada 'iklim duyarlı tasarım' ölçekler için ayrı bir çalışma konusu değil, kentin geleceğini tasvir etmede kullanılan bir yöntem olarak kavramsallaşmaktadır.

\section{I Konut Tasarımı ve İklim}

Binalar kentsel mekanda enerji tüketiminin en temel kaynağıdır. Bina tasarımı ve kullanım şekli, tüketilen enerji miktarını doğrudan etkilemektedir. Sarte'nin (2010) de belirttiği gibi, coğrafi konum, topografya ve bitkilendirme gibi faktörler bir binanın ısıtma, soğutma, havalandırma ve aydınlatma ihtiyaçları için tüketilmesi gereken enerji miktarı üzerinde belirleyici bir role sahiptir. Bu bağlamda, konut tasarımı açısından düşünüldüğünde, güneş ve rüzgar gibi doğal kaynaklardan en üst düzeyde yararlanmayı öngören pasif tasarım yaklaşımı önem kazanmaktadır.

Genel anlamda, binalarda optimum ısıl performansı elde edebilmek için, sıcaklık, nem, rüzgar gibi iklimsel değişkenlerin tamamı tasarım surecinde dikkate alınmalıdır. Ancak, yazında yer alan farklı iklim koşullarına uygun tasarım ölçütlerini evrensel doğru olarak kabul etmek pratikte olumsuz sonuçlar doğurabilir. Her yerel bağlam, kendi iklimsel karakterini ve içerisinde barındırdığı toplumun kültürel ve sosyo-ekolojik değerlerini içerir. Bu nedenle, iklim duyarlı konut tasarımına salt teknik bir problem olarak yaklaşmak yanlış olacaktır. Son kullanıcının (yerel halk) günlük yaşam dinamikleri ve mekanı 
kullanma biçimlerini de kapsayan, diğer bir deyişle sosyo-teknik bir yaklaşım ile toplum, mekan ve iklim arasındaki üçlü ilişkiliyi dikkate alan bir tasarım anlayışı gerekmektedir.

Yazına göre iç mekanlarda termal konforun sağlanması için tüketilen enerji miktarı üzerinde etkili üç temel ölçüt (I) binanın yönelimi, (2) bina formu ve (3) inşaat malzemesidir. Bir binanın, güneşin gün içerisindeki hareket yörüngesi ve hakim rüzgar koşullarına göre yönelimi, bina içerisinde ısıtma ve soğutma faaliyetleri için gerekli olan enerji miktarı üzerinde önemli role sahiptir (Sarte, 2010). Binanın doğru konumu ve yönelimi sayesinde istenmeyen güneş ışıllarından veya rüzgardan sakınmak ya da doğal hava sirkülasyonundan faydalanmak mümkündür (Gut ve Ackerknecht, 2003).

Konutlarda düşük enerji tüketimi ile etkin termal konfor elde edebilmek için, bina formunun doğal kaynaklardan üst düzeyde fayda sağlayacak şekilde tasarlanması gerekir. Bu noktada, Cofaigh vd. (1998) enerji tüketim değerlerinin apartman tipinden müstakil ev tipine doğru artma eğilimi gösterdiğini ileri sürmektedir. Fakat bu kavramsal genelleme her yerel bağlamda aynı eğilimi göstermeyebilir. Örneğin, konutlarda avlu formunun doğal serinletme ve ısıyı depolama kapasiteleri sayesinde, enerji tüketiminde büyük oranda tasarruf sağladığı bilinmektedir (Cofaigh vd. 1998). Öte yandan apartman tipi konutlarda merkezi ısıtma sistemleri sayesinde tüketilen enerjinin haneler arasında paylaşımı sağlanarak farklı tasarruf yöntemleri uygulamak da mümkündür. Bu nedenle enerji tüketim oranlarını salt bina formu üzerinden genellemek doğru olmayacaktır.

Binanın yönelimi ve formu dışında, konutlarda enerji tüketim seviyelerini etkileyen bir diğer ölçüt de konutun inşasında kullanılan malzeme ve dolayısıyla elde edilen duvar kalınlıkları ve ısıl kütledir. Burada, ısıl kütle, kullanılan malzemenin ısıl enerjiyi depolama ve bu sayede ısı geçirgenliğini geciktirme yetisini ifade etmektedir (Energy Design Resources, 2010). Yerel iklim koşullarına cevap verebilen, doğru malzeme seçimi ile yaratılacak etkin ısıl kütlenin, istenen koşullara göre konut içi mekanın serin veya sıcak tutulmasını belirli oranlarda sağlayabildiği söylenebilir. Örneğin, beton, terakota, kireç taşı gibi yoğunluğu yüksek malzemelerin ahşap gibi düşük yoğunluklu malzemelere oranla daha yüksek ısıl kütleye sahiptir (Jeanjean vd., 20I3).

\subsection{Sokak Örüntüsü ve İklim}

İklim duyarlı tasarım yaklaşımının kentsel bağlamda ele alınmasında bir diğer önemli ölçek sokak ölçeğidir. Sokaklar, konut/ bina birimlerinin diziliminden oluşan ulaşım eksenleri olarak tanımlanabilirken, aynı zamanda bir araya getirdikleri örüntü ile kent içi dolaşımı sağlayan temel kent bileşenleridir. Araştırmanın temel odağı bağlamında, sokaklarda termal konforun sağlanması ve bu sayede ulaşıma bağlı enerji tüketim kalemlerinin en temel belirleyicisi olan yürünebilirliğin elde edilmesi, konut/bina ölçeğinde olduğu gibi bir takım fiziksel mekan

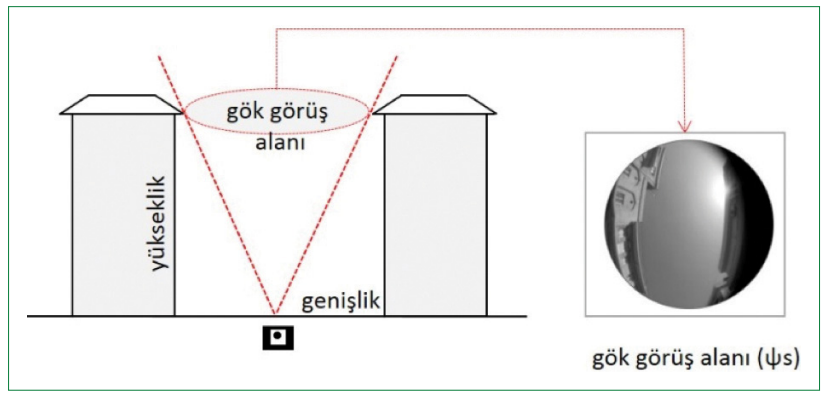

Şekil I. Gök görüş alanı.

organizasyonu kriterlerine bağlıdır. Sokak ölçeğinde yazında vurgulanan üç temel değişken; (I) sokak düzeni, (2) gök görüş faktörü ve (3) gölgelendirme olarak öne çıkmaktadır.

Sokak düzeni, genişlik ve yüksekliklerin belirlenmesiyle kent içi sıcaklık değerleri ve zemin yüzey sıcaklığı üzerinde etkin bir role sahiptir (Bourbia ve Boucheriba, 2010). Gut ve Ackerknecht (1993) sokak düzeni ve mikro iklim ilişkisi açısından farklı tip düzenlerden bahsetmektedir. Bunlardan ilki, direk güneş ışınımına açık olan ızgara düzendir. Gut ve Ackerknecht (1993) Izgara sokak dokusunda maruz kalınan direk güneş ışınlarını kırmanın bir yolunu ızgara sistemin doğu-bati doğrultusunda konumlandırılması olarak belirtmektedir. Bunun yani sıra, kırık ve radyal sokaklardan oluşan düzenlerde istenmeyen güneşışınımları ve rüzgar etkilerinden sakınımda stratejik bir öneme sahiptir. Diğer bir deyişle, doğrusal olmayan sokak düzenleri doğal kaynakların aşırı etkilerinden kaçınmak için etkin bir yöntem sunmaktadır (Gut ve Ackerknecht, 1993).

Sokakların genişliği ve tanımlandıkları binaların yükseklikleri, yazında gök görüş faktörü olarak tanımlanan, açık yüzey alanından alınan güneş ışınımının yarı kürenin toplam ışınım alanına oranı üzerinde (Şekil I) belirleyici bir role sahiptir (Watson \& Johnson 1987).

Gök görüş faktörü 0 ile I arasında değişkenlik gösterir ve bu değerin I'e yaklaşması sokaktaki ışınım oranının artmasını ifade eder. Bir anlamda gök görüş faktörü, termal konforun bir diğer belirleyicisi olan gölgelendirme değişkeni ile doğrudan ilişkilidir. Örneğin, sıcak ve kuru iklimlerde çok geniş ve alçak binalarla tanımlı sokakların güneşe maruz kalma süresi daha fazla olacağından, termal konforun sağlanmasında en temel faktörlerden biri olan gölgelenme süresi de kısalmış olacaktır. Yazında belirtildiği gibi, gölgelendirme solar emilimi azaltma stratejisi olarak önemli bir yere sahipken (Cofaigh vd. 1998), motorlu taşıt kullanımından ziyade yürümeye teşvik eden önemli tasarım değişkenlerinden bir tanesidir.

\subsection{Kent formu ve İklim}

Konut ve sokak ölçeklerindeki mikro iklimsel değişkenliklerin yanı sıra, kent formunun da deneyimlenen kentsel termal 
konfor üzerindeki etkisi ve üst ölçekte iklim değişikliğine katkısı göz ardı edilemez. Yapılan araştırmalara göre, kentsel ısı adaları oluşumunda en etkili olan değişken kentin büyüklüğü iken, kent formu ikinci sırada gelmektedir (Zhou vd, 20I7). Yapılaşma sonucu ortaya çıkan kentsel ısı artışları, rüzgar ve nem değerlerindeki değişiklikler, günlük yaşamda enerji tüketim değerlerini etkilediği gibi, kentsel hava kalitesi, toplum sağlığı ve yaşam kalitesi gibi değerleri etkilemektedir (Yazar, yıl). Örneğin, sıcak ve kurak iklimlerde dar ve gölgeli sokaklar sunan kompakt kent formu mikro iklim değişikliklerini konforlu yönde değiştirecektir (Goulding vd. 1993). Kompakt kent formu aynı zamanda, kent içi ulaşım mesafelerini kısaltacağı için motorlu taşıt kullanımından doğan karbon salımları ve enerji tüketim değerlerinin azaltılmasını destekleyecek bir üst plan stratejisi olarak değerlendirilebilir.

Kent formunun iklim duyarlılı̆ııı belirleyen bir diğer husus ise kentin nefes alma alanları olarak tanımlanabilecek açık ve yeşil alanlar örüntüsüdür. Yapılı çevrenin kent içi sıcaklıkları arttırmasını önlemede açık ve yeşil alan tasarımı önemli bir yere sahiptir. Örneğin sıcak ve kuru iklimlerde, Golany'nin (1996) de belirttiği gibi, geniş ve açık kamusal alanlar, sert zemin kaplamaları veya asfalt gibi ışınımı arttıracak malzemelerle tasarlanmamalı, aksine daha çok, yumuşak zemin malzemeleri, toprak ve bitkilendirmenin yoğun olduğu, gölgelik ve ferahlık etkisi yaratacak geniş yapraklı ağaçlar, su ögeleri, gölgelik ve pergola gibi tasarım elemanları ile kurgulanmalıdır. Araştırmalar, yeşil alanların kent içi serinlik yaratma etkisinin yanı sıra, çevrelerinde yer alan yapıların iç mekan serinlik ihtiyacında ve buna bağlı enerji tüketim değerlerinde azaltma gücünün de olduğunu göstermektedir (Yasin vd, 2020). Bu nedenle, kent formu barındırdığı kütleler ve yeşil alanlar dengesiyle (dolu-boş), kentsel termal konforun sağlanmasında önemli bir değişkendir.

Özetle, kentsel yaşamda termal konforun sağlanması, bina ve iç mekanların yanı sıra, sokaklar ve kent dokusunun oluşumu, ve bu dokuların sunduğu dış mekan konfor düzeyleri ile de ilişkilidir. Tablo I, kentsel konfor bütünlüğünü kurgularken dikkate alınabilecek tasarım değişkenlerini özetlemektedir.

\section{Araştırma Yöntemi}

Yapılı çevrenin kentsel mikro iklim üzerinde yarattı̆̆ı etkiyi ve bu etkinin kentsel yaşamda deneyimlenen termal konfor üzerindeki etkilerini anlamaya çalışan bu araştırmada, Mardin kentinin geleneksel ve modern kent dokuları arasında karşılaştırmaya dayalı bir inceleme yapılmıştır. İki farklı kent dokusunu barındıran Mardin, fiziksel çevrenin günlük termal konforun sağlanmasında tüketilen enerji miktarını nasıl etkilediğini anlamak için özel bir açık laboratuvar niteliği taşımaktadır. UNESCO dünya tarih miras listesine aday olarak gösterilen tarihi kent dokusu, yamaç üzerine konumlandırılmı̧ teras evler
Tablo I. Bina, sokak ve kent ölçeklerinde iklim duyarlı tasarım değişkenleri

\begin{tabular}{|c|c|c|}
\hline Ölçekler & $\begin{array}{l}\text { İklim duyarlı } \\
\text { tasarım değişkenleri }\end{array}$ & Referans \\
\hline \multirow[t]{4}{*}{ Bina } & (I) Binanın yönelimi & Cofaigh vd. (1998) \\
\hline & (2) Bina formu & Gut ve Ackerknecht (2003) \\
\hline & (3) İnşaat malzemesi & Jeanjean vd. (20/3) \\
\hline & & Sarte $(2010)$ \\
\hline \multirow[t]{3}{*}{ Sokak } & (I) Sokak düzeni & Cofaigh vd. (1998) \\
\hline & (2) Gök görüş faktörü & Gut ve Ackerknecht (1993) \\
\hline & (3) Gölgelendirme & Watson ve Johnson (1987) \\
\hline \multirow[t]{4}{*}{ Kent } & (I) Kent formu & Golany (1996) \\
\hline & (2) Dolu-boş dengesi & Goulding vd. (1993) \\
\hline & (3) Yeşil alanlar & Yasin vd. (2020) \\
\hline & & Zhou vd. (20I7) \\
\hline
\end{tabular}

sistemi ile yatay bir kentleşme tipi gösterirken, Cumhuriyet sonrasında ovaya doğru gelişen modern kent dokusu, barındırdığı çok katlı apartmanlar ile dikey bir gelişim sergilemektedir (Şekil 2).

İç ve dış mekanlarda yapılı çevrenin termal konfor üzerindeki etkisi ve günlük yaşam pratiklerini anlamak amacıyla yapılan bu araştırma, sosyo-teknik bir yöntemsel çerçeve ile iki etap halinde kurgulanmıştır. İlk etapta, geleneksel konutlar ile yeni şehirde yer alan apartman daireleri arasındaki termal konfor farkını anlamak için iklim değişkenlerini ölçme ve derinlemesine görüşme teknikleri kullanılmıştır. Teknik ölçümler için geleneksel ve modern mimari örneğini temsilen Şekil 3'te görüldüğü gibi biri geleneksel avlulu konut birimi, diğeri modern apartman dairesi olmak üzere iki örnek konut üzerinden günlük sıcaklık ve nem değerleri izlenmiştir. Ölçümler Testo $174 \mathrm{H}$ ölçüm cihazları ile 15 'er dakikalık aralıklarla Ağustos 2014 'te kaydedilmiştir. İç ve dış mekan farklııklarını tespit edebilmek için, balkon, avlu ve oturma odalarına yerleştirilen dört ayrı cihaz kullanılmıştır.

Teknik ölçümlerin yapıldığı alan çalışması paralelinde, 30 geleneksel konut - 30 apartman dairesi olmak üzere, 60 ayrı konutta toplam 153 kişi ile derinlemesine görüşmeler yapılmıştır. Görüşmelerin amacı, yerel halkın günlük yaşamda mekanı kullanma deneyimlerini anlamanın yanı sıra, günlük yaşam içerisinde hakim iklim koşullarına adaptasyon ve termal konforun sağlanmasında izlenen yöntemleri tespit etmektir.

İkinci etapta ise, geleneksel kent ve modern kent dokularından seçilen örnek sokak dokuları arasında mikro iklimsel değişiklikleri ve yapılı çevrenin termal konfor üzerine etkisini anlamak üzere bir karşılaştırma yapılmıştır. Şekil 4 'te 


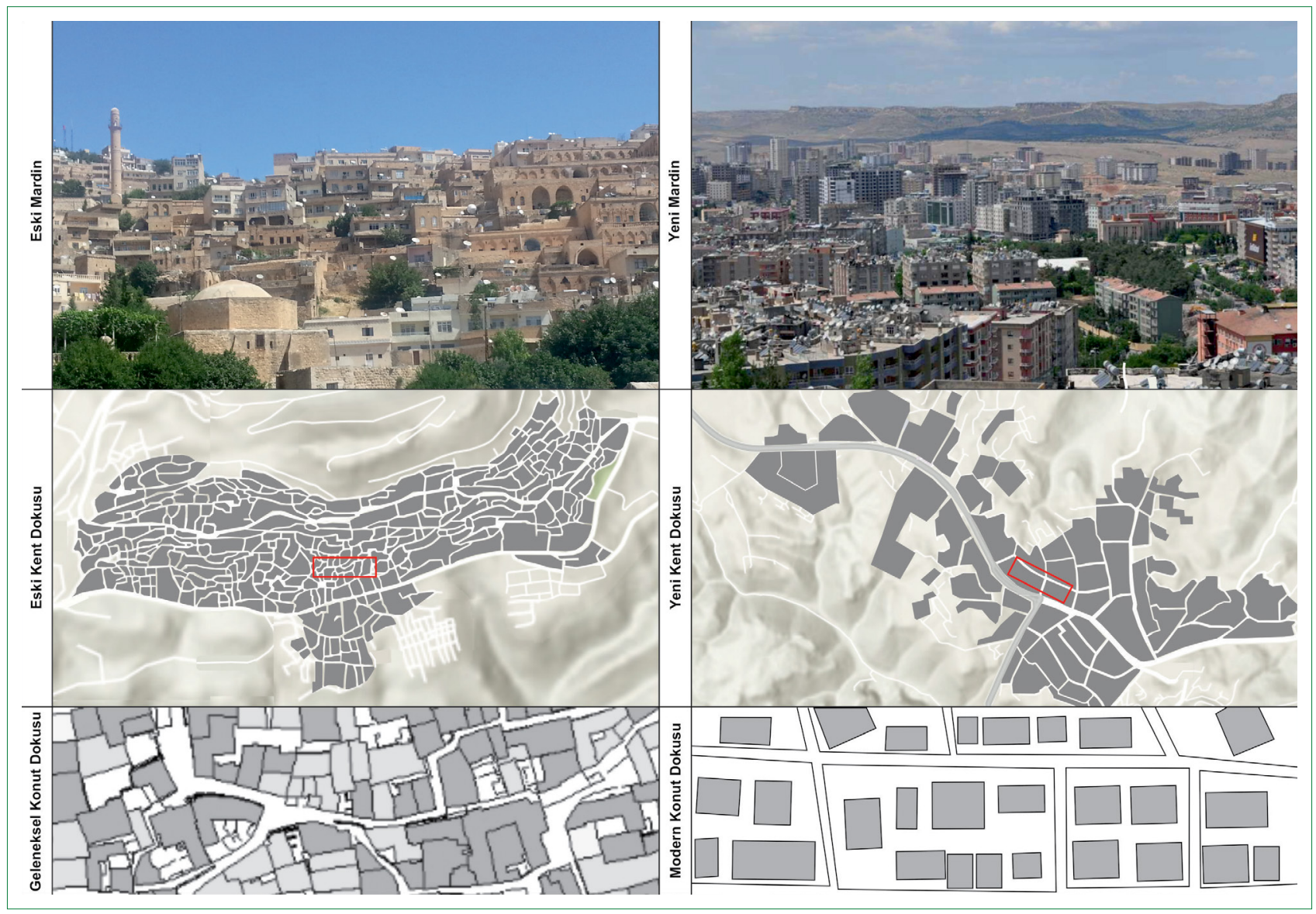

Şekil 2. Mardin ili geleneksel (sol) ve modern (sağ) kent dokusu.

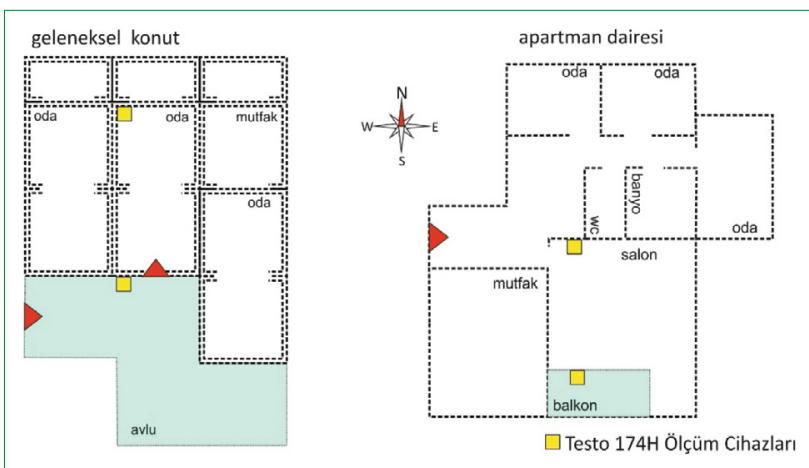

Şekil 3. Ölçüm aletlerinin örnek konut birimlerine yerleşim şeması.

görüldüğü gibi, geleneksel kentten ve yeni kentten arazi kullanımı, taşıt ve yaya birlikteliği açısından benzerlik gösteren iki örnek seçilmiştir.

Bina ölçeğinde izlenen iklim değişkenleri benzer şekilde sokak ölçeğinde de ölçülmüştür. Eş zamanlı olarak (eski ve yeni dokuda) yayaların kent içi sıcaklık, nem, rüzgar ve genel ısıl konfor algılarını karşılaştırmak amaçlı sokak anketleri yapılmıştır. Konut ve sokak ölçeklerinde yapılan araştırmalar, hem teknik anlamda yapılı çevrenin kent içinde yarattığı mikro iklimsel değişiklikleri anlamak, hem de yerel halkın kentsel yaşam içerisinde hakim iklim koşullarına adapte olabilme ve konforlu bir yaşam sürdürebilme düzeylerini anlamak için kurgulanmıştır.

Araştırmanın son aşamasında ise, yapılı çevrenin oluşmasında rol oynayan yerel yönetimler ile derinlemesine görüşmeler yapılmıştır. Görüşmeler sırasında geleneksel doku ve modern doku arasında tespit edilen farklılıklar, geleneksel kent dokusunun sunduğu iklim duyarlı tasarım ipuçları ve modern kentin yapılaşma dinamikleri ile enerji bağımlı kentleşme eğilimi konuları üzerinde durulmuştur. Kentsel gelişme dinamikleri üzerinde karar verme yetkisi olan yerel yönetimlerin iklim duyarlı kentleşme konusundaki farkındalıkları, aldıkları önlemler ve eylem adımlarının tespiti, klimatolojik bilgilerin planlama pratiğine aktarılmasında büyük önem taşımaktadır.

\section{Bulgular ve Tartışma}

Geleneksel ve modern kent dokusu arasında farklı ölçeklerde yapılan karşılaştırmalı analizler, binlerce yıl önce, bugünün teknolojik gelişmelerinin olmadı̆̆ı dönemlerde inşa edilmiş olan tarihi kentin, bugünkü kent dokusuna oranla daha fazla iklime 


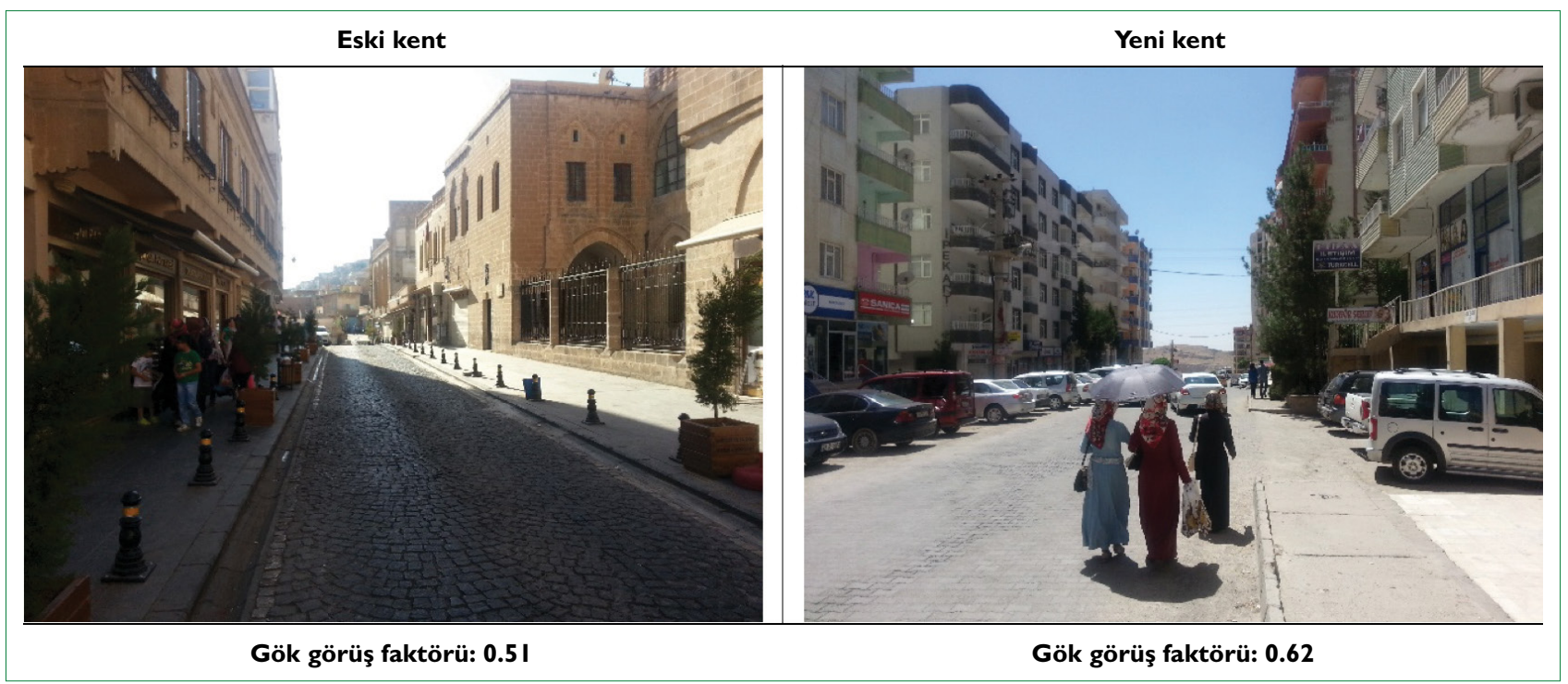

Şekil 4. İki kentten seçilen sokak örneklemleri.

duyarlı olduğunu göstermektedir. Bu duyarlılığa konut, sokak ve şehir ölçeklerinde bakıldığında, tarihi kentte, her ölçek altında dikkat edilmesi gereken birtakım tasarım ölçütleri ve daha da önemlisi şehrin tamamının oluşumunda genel bir tasarım vizyonunun varlığından bahsetmek mümkündür.

Mardin tarihi kent dokusunu oluşturan konutlar, açık-kapalı mekan dengesinin hakim iklim koşullarına uyum gösterecek şekilde sağlandığı, genellikle avlulu, müstakil ve taş konut tipi sergilemektedir. Kuzey-güney doğrultusunda konumlanan geleneksel konutlar, hem güney cephede güneşten maksimum faydayı sağlayan, hem de kuzey cephenin serinlik ve gölge etkisinden faydalanan iç mekan birimlerini barındırmaktadır. Yeni kentin oluşumunda ise konut sunum biçimi tekil veya küme apartman tiplerinden oluşurken, binaların yöneliminde ortak bir tasarım prensibinin olmadığı gözlemlenmektedir. Bu farklılık, iki konut sunum biçimi arasında iklim koşullarına uyum ve cevap verebilirlik açısından değişkenlikler yaratmaktadır.

Mimari ölçekte yapılan teknik ölçümlerde, iki konut tipi arasında iç mekan ve dış mekan sıcaklıklarında değer farklılıkları tespit edilmiştir. Apartman dairesinde balkon ve iç mekan arasında ortalama $2.97^{\circ} \mathrm{C}$ sıcaklık farkı gözlemlenirken, geleneksel avlulu konutta avlu ve iç mekan arasındaki sıcaklık değeri ortalama $6.60^{\circ} \mathrm{C}$ fark etmektedir. İki kent arasındaki rakım farkı (400 m.) göz önüne alındığında ölçüm değerleri arasında yine ortalama $1.7^{\circ} \mathrm{C}$ fark gözlemlenmektedir.

İç ve dış mekan arasındaki sıcaklık değerlerindeki bu değişkenlik, yapı formu ve malzeme bütünlüğü ile açıklanabilir. Geleneksel konut dokusunda kullanılan taş malzeme ve $80 \mathrm{~cm}$ ile $110 \mathrm{~cm}$ arasında değişkenlik gösteren duvar kalınlı̆̆ı, dış mekan sıcaklığının iç mekan termal konforu üzerindeki etkisini önlemektedir. Apartman dairesinde kullanılan $19 \mathrm{~cm}$ kalınlığındaki tuğla duvar ise isi geçirgenlik oranı yüksek olduğundan, iç mekan ısıl konforunda daha hızlı değişime neden olmaktadır.

Yapılan derinlemesine görüşmeler, ölçülen sıcaklık farklılıklarının, kullanıcıların günlük yaşam pratiklerini doğrudan etkilediğini göstermektedir. Yeni şehirde yaşayan katılımcıların \%93'u en az bir soğutma cihazına sahipken, bazı hanelerde bu rakamın 5'e kadar çıktığı gözlemlenmiştir. Bunun yani sıra, yeni şehirde yaşayan katılımcıların \%80'i yaz aylarında klimasız yaşamın imkânsız olduğunu vurgulamaktadır. Geleneksel kentte, katılımcıların \%33'ü klima kullanırken, termal konfor büyük oranda konutların mimari çözümlemeleri ile sağlanmaktadır. Şekil 5, eski ve yeni kentte soğutma cihazlarının kullanım oranları hakkında daha detaylı bir bilgi sunmaktadır.

Şekil 5 'te görüldüğü gibi, geleneksel konutlarda ve apartman dairelerinde, soğutucu cihaz kullanımı açısından iki farklı eğilim söz konusudur. Eski kentte doğal yöntemler, vantilatör ve tavan pervanesi yönünde bir kümelenme gözlemlenirken, yeni kentte klima ağırıklı ve birden fazla cihaz kullanımı yönünde bir dağılım göze çarpmaktadır.

Derinlemesine görüşmeler, klima kullanımına bağlı elektrik tüketiminin son derece yüksek olduğunu ortaya koymaktadır. Ortalama hane büyüklüğü ayni olan aileler arasında yapılan karşılaştırma, yeni kentte aylık ortalama elektrik tüketiminin eski kent ortalamasının iki katı olduğunu göstermektedir. Yerel halk, klima kullanımının yaratmış olduğu elektrik tüketim yükünün farkında olmakla birlikte, yeni şehirde konut içi ısıl konforu sağlamakta başka bir çözüm yolu olmadığını belirtmektedir. Ancak, yeni şehirdeki yaygın klima kullanımı, bina cephelerinde konumlanan klima motorlarından (Şekil 6) salınan gazlar ve ısı aracılığıyla kent içi mikro iklim üzerinde deği- 


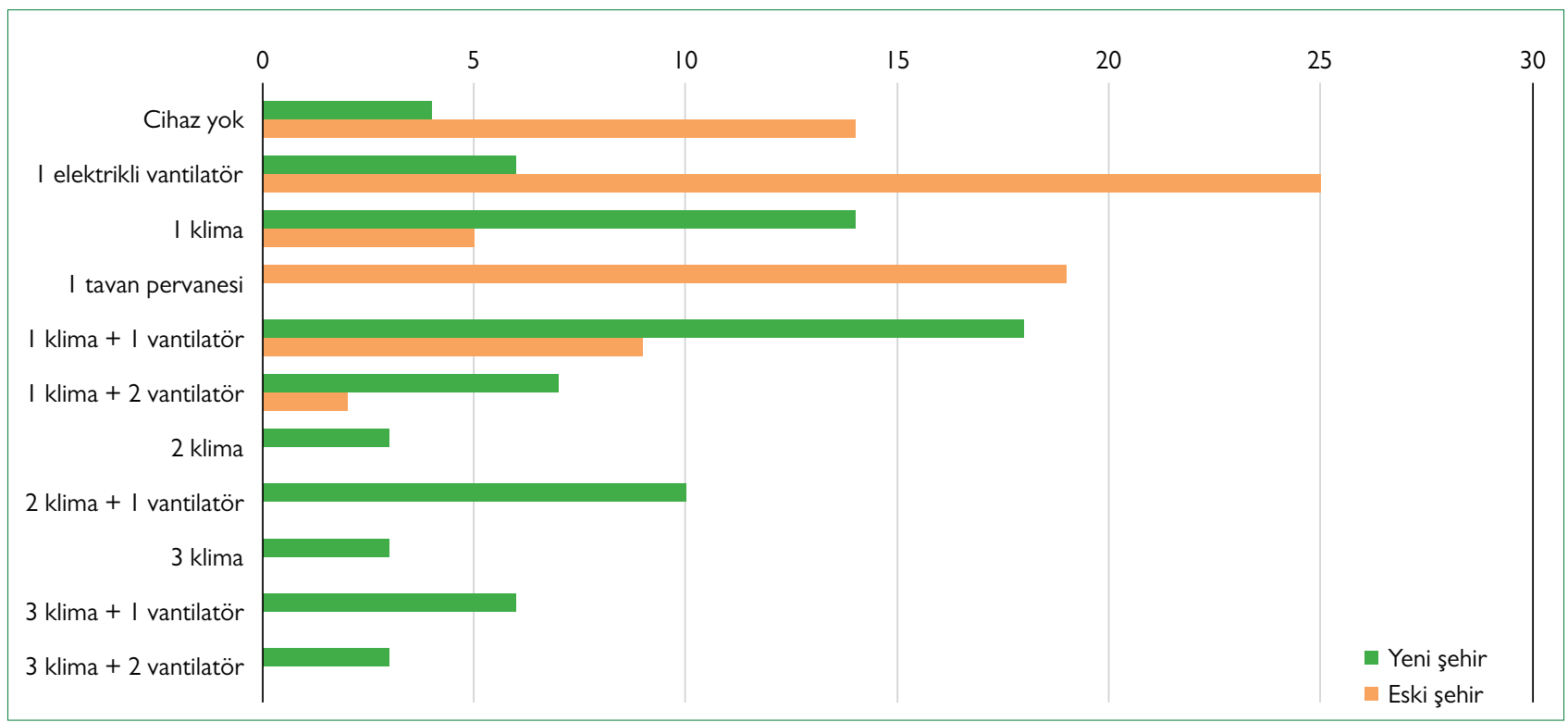

Şekil 5. Yeni ve eski şehirde soğutma cihazları kullanım dağıımı.
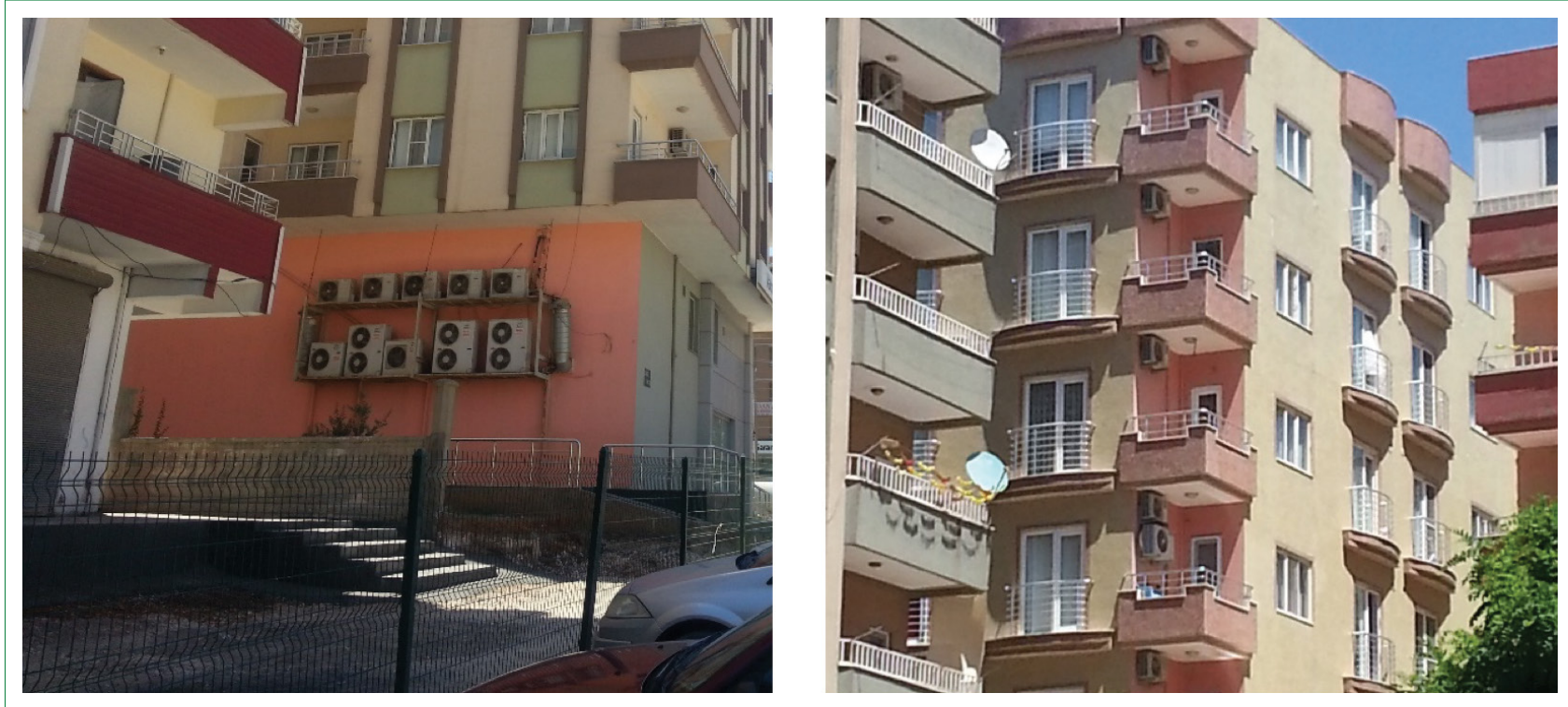

Şekil 6. Yeni şehirde kentsel ısı artımını tetikleyen klima motorları.

şim yaratmaktadır. Bir başka deyişle, konut içi termal konforun sağlanmasında kullanılan cihazlar, kentsel ısı adası oluşumunu tetiklerken, bir yandan da konut içinde soğutma ihtiyacına katkıda bulunarak kısır bir döngü yaratmaktadır.

Teknik ölçümler ve derinlemesine görüşmeler, Mardin ili hakim iklim koşullarına uygun yapılaşma tipinin Türkiye'nin her bölgesinde inşa edilen, basmakalıp (stereotype) apartman blokları olmadığını göstermektedir. Kuşkusuz nüfus, ekonomik kaynaklar ve mülkiyet hakları gibi konulardan ötürü, yeni şehri geleneksel dokudaki avlulu müstakil konutlar ile tasarlamak gerçekçi bir çözüm değildir. Ancak, bu koşullar, hakim yapılaşma ve basmakalıp apartmanlaşma eğilimini devam ettirme gerekliliğini meşru kılmaz. Çok katlı apartman bloklarının yerine, yine dikeyde büyüme ve hektar başına daha fazla nüfus yoğunluğunu barındırabilecek yeni konut tiplerine ihtiyaç duyulmaktadır. Bu tiplere tarihten çıkarılan mimari tasarım kriterlerinin entegre edilmesi, hem hakim iklim koşullarında ısıl konforun sağlanması, hem de iklim değişikliği azaltım politikalarından olan 'daha düşük enerji tüketimi' ve 'daha az karbon salımı' gibi hedeflere sadık kalmayı sağlayacaktır. İçerik analizi sonuçları, geleneksel konut ve apartman dairelerinde yaşayan katılımcıların termal konfor algılarını etkileyen bileşenler arasında farklılıklar olduğunu 
ortaya koymaktadır (Tablo 2). Örneğin, bulgular geleneksel konutlarda termal konforun sağlanmasında en etkin tasarım bileşenlerinin avlu, dam ve teras gibi açık mekanlar olduğunu göstermektedir. Yaz aylarında, günlük yaşam büyük oranda açık mekanlarda geçmektedir. Öte yandan apartman dairelerinde sunulan balkonlar, konutların mekânsal olarak ancak \%।0-\%।5 gibi bir kısmını oluştururken, fonksiyon ve termal konfor açısından geleneksel kentteki açık mekanların yerini tutmamaktadır. Aşağıdaki alıntı bu yetersizliğe bir örnek oluşturmaktadır:

“Tarihi Mardin'de yaşarken çoğu vaktimiz ya avluda geçerdi ya da damda. Geceleri bile açık havada yattığımız olurdu. Burada balkona da çıksan açık hava denemez. Baksana çıkınca zaten karşıdaki apartmanı görüyorsun. Serinlik gelmiyor ki, içerisiyle dışarısı aynı gibi. Dip dibe yaptılar bu binaları. Şimdi sorsalar hayatta taşınmazdım buraya. Çocukların okuluna yakın olalım diye mecbur taşındık." (Yeni kent, 42, Erkek).

Açık mekanları takip eden diğer değişkenler, söylenme sıklığına göre; duvar yapısı, soğutma cihazları, form ve ıslak zeminlere erişim olarak sıralanmaktadır. Duvar yapısı, geleneksel konutlarda olumlu bir değişken olarak algılanırken, apartman dairelerinde olumsuz bir değişken olarak vurgulanmaktadır. Yapılan karşılaştırmalı teknik ölçümler bu algıyı doğrulamaktadır. Benzer şekilde, soğutma cihazlarının söylenme sıklığı arasındaki fark, eski ve yeni konutlarda cihazlara duyulan ihtiyaç dağııım grafiği ile örtüşmektedir. Islak hacimlere erişimin konfor üzerine etkisindeki farklılı̆ı̆n nedeni ise, geleneksel konutların büyük çoğunluğunda ıslak hacimlerin konut dışında yer alması ve belirli dönemlerde bu alanlara erişimin konforsuz bir deneyim sunması ile ilişkilidir.

Konut sunumlarındaki farklılık, kent örüntüsünün temel bileşenleri olan sokakların oluşumunda da düzen ve doku açısından farklılıklar doğurmaktadır. Mardin'de geleneksel kent, konutların taş duvarlarıyla tanımlanmış, dar ve yaya ağılıklı bir sokak örüntüsü sunarken, yeni kent apartman dizilerinden oluşan, taşıt odaklı ulaşıma teşvik eden sokaklar barındırmaktadır. Yapılı çevrenin kent içi mikro iklim üzerindeki etkisini anlamak için yapılan teknik ölçümler de iki farklı sokak düzeninin yarattı̆̆ı kentsel ısıl farkını ortaya koymaktadır. İki sokak dokusu arasında ortalama sıcaklık değerlerinde $4^{\circ} \mathrm{C}$ fark gözlemlenirken, rakım farkı hesaplandığında kalan $2^{\circ} \mathrm{C}$ lik farkı, yapılı çevrenin yarattığı etki ile açıklamak mümkündür. Yapılan sokak anketleri de ölçülen sıcaklık farklılıklarının algılanan kentsel ısıl konfor üzerinde etkisi olduğuna işaret etmektedir. Şekil 7'de görüldüğü üzere, geleneksel kent dokusundan ve yeni şehirden alınan sokak dokusu örneklerinde algılanan ısıl konfor değerleri farklılık göstermektedir. Eski sokak dokusundaki katılımcıların \%54'ü konforlu hissederken, yeni kentte konforlu hissedenlerin oranı \%22'ye düşmektedir. Benzer şekilde memnuniyetsizlik oranı eski kentte $\% 21$ iken, yeni kentte bu oran \%38 olarak görülmektedir.
Tablo 2. Termal konfor algısını etkileyen değişkenlerin söylenme sıklığı

\begin{tabular}{|c|c|c|c|}
\hline İçerik grupları & Alt değişkenler & Eski (\%) & Yeni (\%) \\
\hline \multirow[t]{4}{*}{ Açık mekan uzantıları } & Avlu & 40 & 36 \\
\hline & Teras & & \\
\hline & Bahçe & & \\
\hline & Balkon & & \\
\hline \multirow[t]{3}{*}{ Duvar yapısı } & Kalınlık & 14 & 27 \\
\hline & Malzeme & & \\
\hline & Yalıtım & & \\
\hline \multirow[t]{3}{*}{ Soğutma cihazları } & Klima & 9 & 23 \\
\hline & Vantilatör & & \\
\hline & Tavan pervanesi & & \\
\hline \multirow[t]{2}{*}{ Form } & Yapı formu & 17 & II \\
\hline & Tavan formu & & \\
\hline \multirow[t]{2}{*}{ Islak hacimlere erişim } & Mutfak & 13 & 1 \\
\hline & Banyo\&tuvalet & & \\
\hline \multirow[t]{2}{*}{ Diğer } & Odalar arası bağlantı & 7 & 2 \\
\hline & Odaların çeşitliliği & & \\
\hline Toplam & & 100 & 100 \\
\hline
\end{tabular}

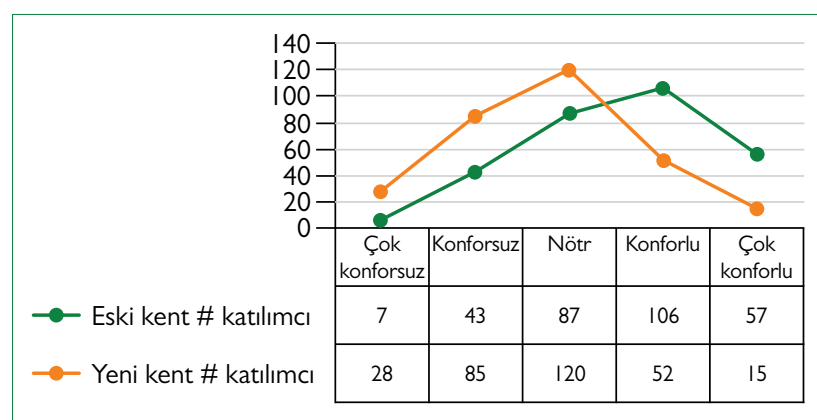

Şekil 7. İki sokak dokusunda algılanan ısıl konfor seviyeleri.

Katılımcıların kentsel termal konfor algıları büyük oranda güneşe maruz kalma ve gölgelik alanlardan faydalanabilme faktörleri ile doğru orantı göstermektedir. Geleneksel kentte güneşin gün içerisindeki hareketini dikkate alan sokak konumlandırma stratejisi, gün boyu gölgelik alanların oluşmasını sağlarken, yeni kentin sokak örüntüsünde belirli bir yönelim prensibi tespit edilememiştir. Geleneksel kentte doğu-batı eksenli uzanan sokaklar, sabah güneşin doğumundan öğlen saatlerine kadar sokağın bir tarafında, öğleden sonra güneş batıya doğru yöneldiğinde ise, sokağın diğer tarafında gölge yaratacak şekilde konumlanmıştır. Gölgelik alanların varlığı, sıcak ve kuru iklim koşullarına sahip Mardin ilinde, yaz ayları için yürünebilirlik prensibinin en temel belirleyicisidir. Yapılan görüşmeler yeni şehirde, özellikle kadınların, gün batımından önce sokağa çıkmayı tercih etmedikleri, acil ihtiyaç 
duyduklarında kısa mesafelerde motorlu taşıtlar ile ulaşım sağladıklarını göstermektedir. Kadınların daha fazla etkileniyor olmasının altında dini inanç gereği giyim koşulları (başörtüsü, pardösü vb.) ve bu giyim ihtiyaçlarının yazlık/termal olanlarına erişim maliyetlerinin yüksek olması yatmaktadır. Halbuki iklim dostu kentlerde yürünebilir sokaklar yaratmak en temel kriterler arasında yer almaktadır. Katılımcılardan gelen aşağıdaki alıntı, konfor probleminin yürüme ile ilişkisini örneklemektedir:

"Sıcak havalarda yaşam duruyor bizim için. Markete gitmek için eşimi bekliyorum mesela. İş çıkışı arabayla gidiyoruz. Bir iki parça bile alacak olsam bekliyorum ne yapayım? Aslında o kadar uzak bir mesafe değil ama bu sıcakta onları taşımak imkansız. Insan normal zor yürüyor, bir de elinde poşetlerle düşün.” (Yeni kent, 35, Kadın).

Konforlu yürüme deneyimi, aynı zamanda eski ve yeni kentin formları ile de yakından ilişkilidir. Eski kentin kompakt for$\mathrm{mu}$, bir yandan gölge veren sokak oluşumlarına izin verirken, bir yandan da farklı kentsel kullanımlar arasındaki mesafeleri yürünebilir kılmaktadır. Kompakt form, taşıt bağımlılı̆ını azaltırken, saçaklanan kent formu, kentin farklı parçaları arasındaki ulaşımın motorize taşıtlar aracılığıyla yapılmasına imkan vermektedir. Örneğin, konut - çalışma alanları arasındaki kent içi yolculuklar, eski kentte \%30'u yürüyerek, \%।8'i özel araçla ve \%52'si minibüs ile yapılırken; yeni kentte \%।3'ü yürüyerek, \%38'i özel araçla ve \%49'u minibüs ile yapılmaktadır. Kent formunun yürüme üzerindeki etkisi aynı zamanda kentsel ulaşımdan kaynaklı karbon emisyon miktarlarını da etkilemektedir Kent büyüklügüu, nüfus, arazi kullanımındaki çeşitlilikler göz önünde bulundurulduğunda, kentsel termal konforu sadece formun belirlediği mesafeler konusu üzerinden düşünmemek gerekir. Yeni kentin, eski kente oranla daha geniş bir coğrafyada büyüdüğü aşikardır. Ancak, daha fazla alana yayılan kent formunda, açık ve yeşil alanlar, bu alanların yapılı kütleler ile ilişkisi ve kent içerisindeki dengeli dağılımı önem kazanmaktadır.

Konut, sokak, ve kent ölçeklerinde yapılan ölçüm ve görüşmeler, geleneksel kent dokusunun modern kente göre iklim koşullarına daha duyarlı olduğunu ortaya koymaktadır. Bu duyarlılık hem hakim iklim koşullarına uyum gösterme hem de kentsel iklim değişikliği yaratma açısından iki boyut taşımaktadır. Kuşkusuz termal konfor günlük yaşam kalitesi göstergelerinden sadece bir tanesidir ve hiçbir kent salt termal konforu sağlamak için planlanmaz. Bu araştırmanın vurgulamak istediğ temel nokta, iklim ile bağlantılı olan termal konfor konusunun planlama disiplinin barındırması gerektiği pek çok alt konu ile ilişkili olmasıdır. Örneğin yürünebilir sokaklar oluşturmak, kent içi nefes alma alanlarını (yeşil alan vb.) arttırmak, güneş, rüzgar, nem gibi klimatolojik değişkenleri planlamanın her ölçeğinde göz önünde bulundurmak, iklim değişikliği açısından büyük önem taşıyan enerji tüketimi konusunda son derece etkin role sahiptir. Örneğin, aşağıdaki alıntı Mardin yeni kentte sayıları az olan kent içi yeşil alanların termal konfor açısından nasıl bir kaçış mekanı oluşturduğunu örneklemektedir:

"Akşamları buraya atıyoruz kendimizi. Evlerin içi durulamayacak kadar bunaltıcı oluyor. Bir de çocuklar var. Insan oturduğu yerde terliyor, çocukları düşün, zaten çok hareketliler. En azından burada parkta oynuyorlar biz de biraz da olsa serinliyoruz. Yalnız akşamları yer kapmak gerekiyor, aileler buraya geliyor. Başka yer yok çünkü yakında.” (Yeni kent, 32, Kadın).

Mekan üretiminde iklime duyarlılık konusu, kentlerin oluşumunda temel yol gösterici belge olarak hazırlanan I/5000 ölçekli Nazım İmar Planı ve I//000 Uygulama İmar Planları ile doğrudan ilişkilidir. Örneğin, konut ve çalışma alanları arasında uzun ulaşım mesafeleri bırakan yanlış arazi kullanım kararları, motorlu taşıt kullanımı ve beraberinde daha fazla karbon salınımını tetikleyen, iklimi yok sayan bir planlama kararını örneklemektedir. Kentlerimizin birçoğunda TOKI tarafından, yerel belediyelerden bağımsız olarak belirlenen konut alanları arazi secim ve tasarım kriterlerinin iklim konusunda duyarlılık göstermediği görülmektedir. Örneğin, Mardin'de kentin kuzey batısında seçilen TOKI konut alanı (Şekil 8), kent planından bağımsız, dolayısıyla mekânsal bütünlükten uzak, parçacıl bir yer seçim kararını örneklemektedir.

Şekil 8'den izlenebildiği gibi, eski şehrin kompakt formuna karşıt, yeni şehirde kent formu tanımlanamayacak şekilde saçaklanmaktadır. Bu saçaklanma, beraberinde birçok kentsel altyapı ve ulaşım sorununu doğurmaktadır. Kent çeperinde parça parça yükselen apartman blokları, termal konfor çözüm arayışlarını bina ölçeğinde ve dışsal soğutma cihazlarına bağlı bırakmaktadır. Bu konutlar, bütünde bir kentsel sisteme bağlanmamaktadır.

Özellikle kentin kuzeyinde yükselen konutlar, parçacı bir planlama anlayışının ürünü olarak, özel mülkiyet üzerinde verilen yapılaşma haklarının uygulamaya geçtiğinde ortaya çıkan mekânları temsil etmektedir. Kent planlamanın, salt mülkiyet hakları üzerinde yapılaşma koşullarının belirlenmesi olarak algılanması sonucunda, sağlıklı ulaşım, yaya yolları ve standartlara uygun yeşil alanlardan yoksun, Şekil 9'da örneklenen mekan tipleri üremektedir. Bu mekanların artan sıcaklıklar ve olası sıcak dalgalarına dirençli olduklarını söylemek oldukça zordur.

Halbuki, plan yapma yetkisine sahip olan belediyeler, hem hakim iklim koşullarına uygun şehirleşme koşullarının belirlenmesi hem de iklim değişikliği konusunda sorumlu oldukları kentin etkisini azaltmaya yönelik çalışmaların başlatılması için yetkiye sahiptir. Burada temel nokta, kentlerimizi tasarlama anlayışının eksikliğidir. Kuşkusuz kentsel mekan üretimi, mülkiyet hakları ile doğrudan ilişkilidir. Ancak bu ilişki, bütüncül bir tasarım anlayışının planlama süreçlerine entegre edilmesine engel değildir. Geleneksel kentte gözlemlenen iklim duyarlı 


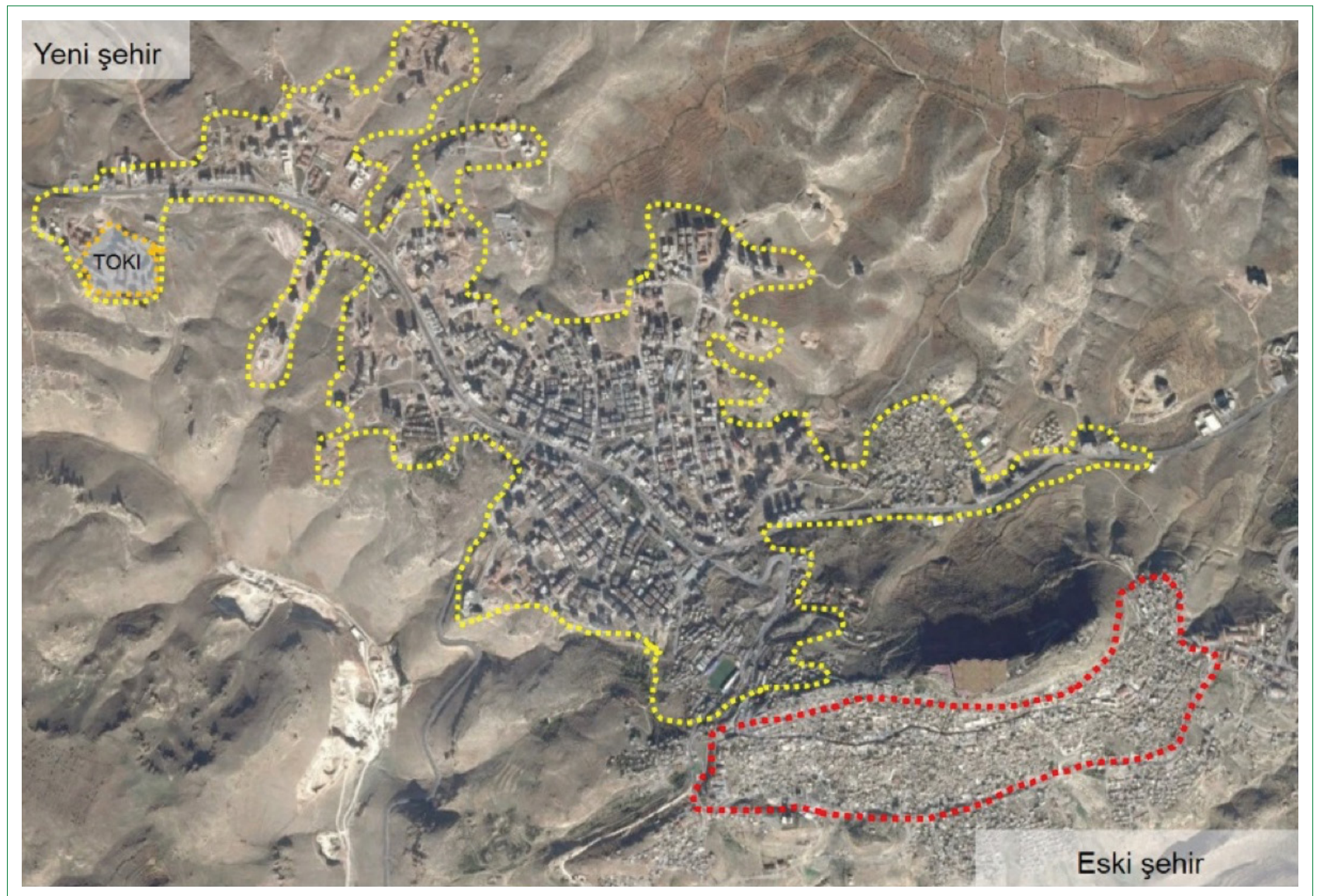

Şekil 8. Eski kentin derişik formu ve yeni kentte saçaklanma problemi.

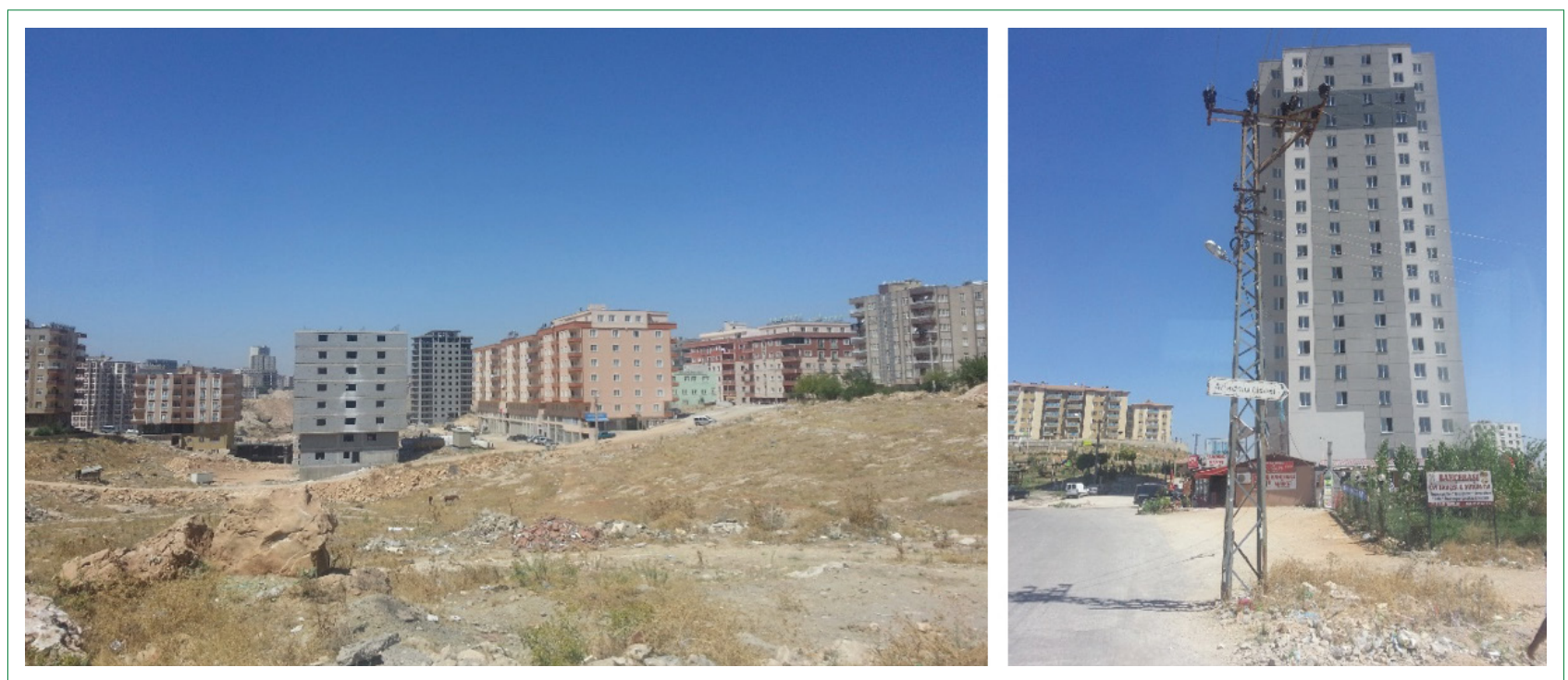

Şekil 9. Altyapı ve sosyal donatıları eksik konut alanlarından örnekler.

kentsel tasarım prensiplerinden ders çıkarıp, bu prensipleri yeni yapılaşma alanlarında güncel koşullara yansıtmak mevcut planlama mevzuatında büyük değişiklikler gerektirmeden yapılabilir. Ancak bunun için yerel yönetimlerde farkındalığı art- tırma, iklim değişikliği, kentleşme ve enerji konularında uzman personel istihdamı ve farklı planlama birimleri arasında işbirliği içerisinde çalışma kültürünü oluşturmak gerekmektedir. Bu işbirliği alt ölçekten üst ölçeğe bütün mekânsal politikaların 
oluşumu için önemlidir. Örneğin yapılaşmanın temel bileşenlerinden olan inşaat malzemeleri ve bina tiplerinin iklime duyarlıık açısından yeniden ele alınması için, belediyelerde yer alan Yapı Kontrol Şube Müdürlükleri, il Şehircilik Müdürlükleri bünyesindeki Yapı Denetim ve Malzeme Müdürlüğü gibi etkin birimler işbirliği içinde çalışabilir. Mevcut yapılaşma eğilimlerinin devamı ve takibinin bir adım ötesine geçerek, yenilikçi ve iklim dostu çözüm arayışları üzerine çalışmalar yapılmalıdır. Yerel iklim koşullarına uygun olarak üretilecek bu çalışmalar, İmar ve Şehircilik Müdürlüğü gibi diğer planlama birimleri ile işbirliği içerisinde kentin bir bütün olarak tasarlanmasına katkıda bulunacaktır.

Şehircilikte iklim duyarlılık vizyonunun eyleme dönüşebilmesi için, ülkesel ölçekte sürdürülen uyum politikalarının, yerel ölçekte mekan üretim süreçlerine nasıl yansıtılacağııın netleştirilmesi gerekmektedir. Örneğin, araştırma sırasında Mardin ilinde, Çevre ve Şehircilik Bakanlı̆ıı tarafından hazırlanan İklim Değişikliği Eylem Planı'nın yerel yönetim nezdinde uygulama ve takibinden sorumlu tek bir kişinin görevli olduğu tespit edilmiştir. Üstelik bu takibin nasıl yapılacağı, ülkesel stratejilerin hangi yöntemlerle yerelde uygulanabileceğine dair herhangi bir resmi izleme kaynağı bulunmamaktadır. Halbuki eyleme yönelik bilginin üretilmesi ve planlama pratiğine yansıtılması, konusunda uzman kişilerden oluşan bir veya birkaç komisyon/alt çalışma gurupları ihtiyacı doğurmaktadır. Zira İklim Değişikliği Eylem Planı şehircilik bağlamında sadece genel bir çerçeve sunmaktadır, belediyelerin bu çerçeveye bağlı kalarak uygulamada ne gibi yöntemler izleneceği yoruma açıktır ve tamamen belediyelerin inisiyatifindedir. Ayrıca İklim Değişikliği Eylem Planı'nın eyleme geçirilmesi konusunda Şehircilik II Müdürlüğü ve Belediye arasında nasıl bir işbirliği ve çalışma mekanizması olduğu da açık değildir.

\section{Son söz}

Bu araştırma, içinde yaşadığımız kentlerde fiziksel mekan oluşumunun kentsel termal konforun şekillenmesindeki önemini vurgulayarak, günümüz kentleşme eğilimlerinin hakim iklim koşullarını göz ardı etmesi ve dengesiz kaynak tüketimleriyle iklim değişikliğine katkıda bulunduğunun altını çizmektedir. Kuşkusuz kentlerde termal konforun sağlanması, şehircilik disiplininde iklim konusunda dikkat edilmesi gereken alanlardan sadece bir tanesidir. Ancak, kentlerin enerji kaynaklarının tüketimindeki rolü göz önüne alındığında, yapııı çevrenin oluşumun süreçlerinde iklimsel bilginin entegrasyonu büyük önem taşımaktadır.

Mardin örneği, barındırdığı iki kent dokusu ile iklim ve tasarım arasındaki döngüsel ilişkiyi anlamak için bir fırsat sunmaktadır. Araştırma, mimari, sokak ve kent ölçeklerinde iklime duyarlı mekan üretiminde dikkat edilmesi gereken tasarım prensiplerinin altını çizerken, hakim planlama uygulamalarının farklı ölçeklerdeki nüansları tam olarak barındırmadığını vurgulamaktadır. Araştırma, tarihi kentin sunduğu dar sokaklar, avlulu yapılar gibi iklim çözümlerinin günümüz kentlerde tekrarlanmasının ya da kopyalanmasını savunmak yerine tarihi dokunun ortaya çıkışındaki bütüncül, üst düzey tasarım nosyonuna dikkat çekmektedir. Burada, mimari, sokak ve kent ölçekleri arası harmoni ve bu uyumun nasıl bir bütünlük oluşturduğu önemlidir.

Türkiye'de iklime duyarı kentlerin oluşmasında en büyük engel, hakim kent planlama anlayışının kentsel araziler üzerinde mülkiyet ve yapılaşma haklarının yeniden düzenlenmesinin ötesine geçilememesidir. Kentsel arazilerin, salt yapılaşmanın gerçekleşeceği zemin olarak algılanması, kontrolsüzce birbirine eklemlenen yapı blokları ve bir araya geldiklerinde sağııkı bir çevre oluşturmayan, yetersiz açık ve yeşil alanları ile iklim koşullarına cevap veremeyen, kentsel yaşamda enerji tüketimine bağımlılı̆̆ı destekleyen mekanlar üremektedir. Kuşkusuz bu algının değişmesi kısa vadeli bir hedef değildir. Bu değişimin, kent planlamasında karar verme mekanizmalarında söz sahibi olan liderlerde olması gerektiği gibi, sadece kendi parseli üstünde yapılaşma haklarını arttırmaya odaklanmış olan bireyler düzeyinde de gerçekleşmesi gerekmektedir. Bu da ancak, iklim eylemine kolektif yöntemlerle geçmekle başarılabilir. Yerel iklim eyleminde, halkın ve tüm aktör gruplarının planlamaya katılımı, karşııklı öğrenme ve diyalog mekanizmaları doğuracaktır. İklim meselesi, bir meslek grubu ya da kurumsal otoritenin (müdürlük, başkanlık vb.) çalıştığı yan bir konu (tercih meselesi) olarak algılanmaktan çıkarılıp, kentsel mekan üretimini yatay eksende kesen tüm planlama ölçeklerinde ilgili aktör grupları ile birlikte ele alınmalıdır. 


\section{KAYNAKLAR}

Bourbia, F. \& Boucheriba, F. (2010). Impact of street design on urban microclimate for semi arid climate (Constantine). Renewable Energy, 35(2), 343-347.

Cofaigh, E., Olley, J., \& Lewis, O. (1998). The Climatic Dwelling: An introduction to climate-responsive residential architecture. London: James \& James Ltd.

Deb, C. \& Ramachandraiah, A. (2011). A simple technique to classify urban locations with respect to human thermal comfort: Proposing HXG scale. Building and Environment, 46, 1321-1328.

Energy Design Resources. (2010). Design brief: design for your climate, Architectural Energy Corporation, Boulder, CO.

Erell, E., Pearlmutter, D. \& Williamson, T. (2010). Urban Microclimate: De signing the Spaces between Buildings. London: Earthscan Publishing.

Gao, Y., Yao, R., Li, B., Türkbeyler, E., Luo, Q. \& Short, A. (2012). Field studies on the effect of built forms on urban wind environments. Renewable Energy, 46, 148-154.

Golany, G. S. (1996). Urban design morphology and thermal performance. Atmospheric Environment, 30(3), 455-465.

Goulding, J., Lewis, O. \& Steemers, T. C. (1993). Energy Conscious Design. London: B. T. Batsford Ltd.

Gut, P. \& Ackerknecht, D. (1993). Climate Responsive Building: Appropriate Building

Construction in Tropical and Subtropical Regions. Retrieved from. http:// collections.infocollections.org/ukedu/en/d/Jsk02ce/3.3.html

Hyde, R. (2000) Climate Responsive Design, London: Taylor \& Francis Group.

IPCC (2007). Climate Change 2007: Impacts, Adaptation and Vulnerability. Contribution of Working Group II to the Fourth Assessment Report of the Intergovernmental Panel on Climate Change, M.L. Parry, O.F. Canziani, J.P. Palutikof, P.J. van der Linden and C.E. Hanson, Eds., Cambridge University Press, Cambridge, UK, 976 pp.

Jeanjean, A., Olives, R. ve Py, X. (2013). Selection criteria of thermal mass materials for low-energy building construction applied to conventional and alternative materials. Energy and Buildings, 63, 36-48.

Ochoa, C. E. \& Capeluto, I. G. (2008). Strategic decision-making for intelligent buildings: Comparative impact of passive design strategies and active features in a hot climate. Building and Environment, 43(11), 1829-1839.

Oke, T. R. (1987). Boundary layer climates. Cambridge: Cambridge University Press.

Krüger, E. L., Minella, F. O. \& Rasia, F. (2011) Impact of urban geometry on outdoor thermal comfort and air quality from field measurements in Curitiba, Brazil. Building and Environment, 46, 621-634.

Sarte, S. B. (2010). Sustainable Infrastructure: The Guide to Green Engineering and Design. USA: John Wiley \& Sons.

Shashua-Bar, L., Tsiros, X. I., Hoffman, M. (2012). Passive cooling design options to ameliorate thermal comfort in urban streets of a Mediterranean climate (Athens) under hot summer conditions, Building and Environment, 57, 110-119.

Şahin, Ü. (2019) Sıcak Dalgaları: İklim Değişikliğiyle Artan Tehdit ve SıcakSağlık Eylem Planları, Politika Notu, İstanbul Politikalar Merkezi.

UCCRN (2018) Second Assessment Report of the Urban Climate Change Research Network, (eds.) Rosenzweig C., W. Solecki, P. Romero-Lankao, S. Mehrotra, S. Dhakal, T. Bowman, and S. Ali Ibrahim. Columbia University. New York.

Watson, I. \& Johnson, G. (1987). Graphical estimation of sky view-factors in urban environments, Journal of Climatology, 7, 193-197.

Yao. R., Luo, Q. \& Gao, Y. (2012). Simulations of urban microclimates, CIBSE ASHRAE Technical Symposium, Imperical College, London.

Yasin, T., Blocken, B., Maiheu, B. ve van Heijst, G. (2020) More Than a Green Space: How Much Energy Can an Urban Park Save? Proceedings Book,
International Conference on Production of Climate Responsive Urban Built Environments, Istanbul Policy Center

Zhou, B., Rybski, D., \& Kropp, J. P. (2017). The role of city size and urban form in the surface urban heat island. Scientific reports, 7(1), 1-9. 